Daniel A. Barrio · Patricia A. M. Williams

Ana M. Cortizo $\cdot$ Susana B. Etcheverry

\title{
Synthesis of a new vanadyl(IV) complex with trehalose (TreV0): insulin-mimetic activities in osteoblast-like cells in culture
}

Received: 24 September 2002/ Accepted: 10 December 2002/Published online: 13 February 2003 (C) SBIC 2003

\begin{abstract}
Vanadium compounds show interesting biological and pharmacological properties. Some of them display insulin-mimetic effects and others produce antitumor actions. The bioactivity of vanadium is present in inorganic species like the vanadyl(IV) cation or vanadate $(V)$ anion. Nevertheless, the development of new vanadium derivatives with organic ligands which improve the beneficial actions and decrease the toxic effects is of great interest. On the other hand, the mechanisms involved in vanadium bioactivity are still poorly understood. A new vanadium complex of the vanadyl(IV) cation with the disaccharide trehalose (TreVO), $\mathrm{Na}_{6}$ $\left[\mathrm{VO}(\mathrm{Tre})_{2}\right] \cdot 4 \mathrm{H}_{2} \mathrm{O}$, here reported, shows interesting insulin-mimetic properties in two osteoblast cell lines, a normal one (MC3T3E1) and a tumoral one (UMR106). The complex affected the proliferation of both cell lines in a different manner. On tumoral cells, TreVO caused a weak stimulation of growth at $5 \mu \mathrm{M}$ but it inhibited cell proliferation in a dose-response manner between 50 and $100 \mu \mathrm{M}$. TreVO significantly inhibited UMR106 differentiation (15-25\% of basal) in the range 5-100 $\mu \mathrm{M}$. On normal osteoblasts, TreVO behaved as a mitogen at 5-25 $\mu \mathrm{M}$. Different inhibitors of the MAPK pathway
\end{abstract}

\author{
S.B. Etcheverry $(\bowtie)$ \\ Cátedra de Bioquímica Patológica \\ and CEQUINOR (Centro de Química Inorgánica), \\ Facultad de Ciencias Exactas, \\ Universidad Nacional de La Plata, 47 y 115, \\ 1900 La Plata, Argentina \\ E-mail: etchever@biol.unlp.edu.ar \\ Tel.: + 54-221-4235333 \\ Fax: + 54-221-4259485 \\ D.A. Barrio - A.M. Cortizo \\ Cátedra de Bioquímica Patológica, \\ Facultad de Ciencias Exactas, \\ Universidad Nacional de La Plata, \\ 47 y 115, 1900 La Plata, Argentina \\ P.A.M. Williams \\ CEQUINOR (Centro de Química Inorgánica), \\ Facultad de Ciencias Exactas, \\ Universidad Nacional de La Plata, \\ 47 y 115,1900 La Plata, Argentina
}

blocked this effect. At higher concentrations $(75-100 \mu \mathrm{M})$, the complex was a weak inhibitor of the MC3T3E1 proliferation. Besides, TreVO enhanced glucose consumption by a mechanism independent of the PI3-kinase activation. In both cell lines, TreVO stimulated the ERK phosphorylation in a dose- and time-dependent manner. Different inhibitors (PD98059, wortmannin, vitamins $\mathrm{C}$ and E) partially decreased this effect, which was totally inhibited by their combination. These results suggest that TreVO could be a potential candidate for therapeutic treatments.

Keywords Diabetes mellitus - Insulin mimics · Osteoblasts $\cdot$ Signal transduction $\cdot$ Vanadium

\section{Introduction}

Vanadium is an ultra trace element present in higher plants and animals [1, 2]. It has been demonstrated that vanadium compounds present interesting biological and pharmacological properties. In particular, they show insulin-mimetic activity both in vivo and in vitro studies $[3,4,5,6]$. Vanadium promotes glucose transport and metabolism, lipid synthesis, DNA and protein synthesis and has also mitogenic effects on different cell types [7, 8, $9,10,11,12,13]$. In vitro studies have shown that both vanadate and vanadyl decrease lipolysis and stimulate glucose oxidation, glucose transport, glycogen synthase and tyrosine phosphorylation in rat adipocytes $[14,15$, 16]. In addition, vanadate stimulates glucose uptake, glycogen synthase, glycolysis and glucose oxidation in skeletal muscle [17].

At pharmacological concentrations, vanadium derivatives are interesting as potential therapeutic agents. Many vanadium compounds behave as insulin mimics and others display antitumor activity [18, 19]. Once absorbed, vanadium compounds distribute among different tissues and, finally, vanadium is mainly stored in bone [1]. It has been previously shown that vanadium deprivation induced skeletal deformation in the forelegs 
of goats [20]. We have earlier reported the effect of different vanadium derivatives on bone-related cells like fibroblasts and osteoblasts in culture [13, 21, 22, 23, 24, 25, $26,27]$, with vanadium(V) compounds being in general more toxic than vanadium(IV) complexes. Besides, at low concentrations, most vanadium derivatives are weak mitogens in comparison with insulin and exert cytotoxic effects at high concentrations. They also inhibit osteoblastic differentiation, induce morphological alterations and stimulate glucose consumption.

As is well known, insulin signal transduction is mediated through a complex cascade network of reversible protein phosphorylations and dephosphorylations. The earliest event in insulin actions is the autophosphorylation and stimulation of the tyrosine kinase activity of the $\beta$-subunit insulin receptor, induced by insulin binding to the $\alpha$-subunit [28]. Subsequently, insulin receptor tyrosine kinase phosphorylates endogenous substrates such as IRS-1 (insulin receptor substrate-1), which has been the most widely characterized. After that, a cascade of phosphorylation takes place downstream; protein kinases activated by mitogens (MAPK) and ribosomal protein kinases ( $\mathrm{p} 90^{\mathrm{rsk}}$ ) become activated, which, in turn, induce different events. Most evidence suggests that phosphatidyl inositol-3 kinase (PI3-K) is the major link between IRS-1 and the metabolic effects of insulin, while GRB2 (the molecule that connects IRS-1 to the Ras pathway) may be the major link to the growth promotion effect of insulin [28].

Numerous studies have been carried out in order to elucidate the putative mechanisms of action of vanadium derivatives. The insulin-mimetic effects of vanadium would be the result of its behavior as a phosphate analogue and as such it can stimulate the protein tyrosine phosphorylation through the inhibition of protein tyrosine phosphatases (PTPases) $[29,30]$ or by direct stimulation of the kinases [31]. In vitro and in vivo studies demonstrated that vanadium affects different aspects of the insulin signalling pathway. MAPK cascade is one of the major signalling pathways apparently involved in vanadium biological effects. The major subfamilies of structurally related MAPKs that have been identified in mammalian cells are the extracellular signal-regulated kinases (ERKs), the c-jum $\mathrm{N}$-terminal kinases (JNKs) and the p38 MAPkinases (p38s) [32, 33, 34]. ERKs are activated by various growth factors, which act through receptor tyrosine kinases (RTKs) like the platelet-derived growth factor (PDGF) $[35,36]$ and the insulin-like growth factor-1 (IGF-1) [37]. Moreover, the ERK pathway is usually associated with cell proliferation and protection from apoptosis [38].

Srivastava and co-workers [39] reported that the stimulation of the ras-ERK cascade by vanadyl sulfate is dependent on PI3-K activation and it is suggested that the stimulation of the PI3-K/ras/ERK pathway plays a key role in mediating the insulin-mimetic effects of inorganic vanadium salts. It has been shown that several vanadium salts activate MAPK and two ribos-

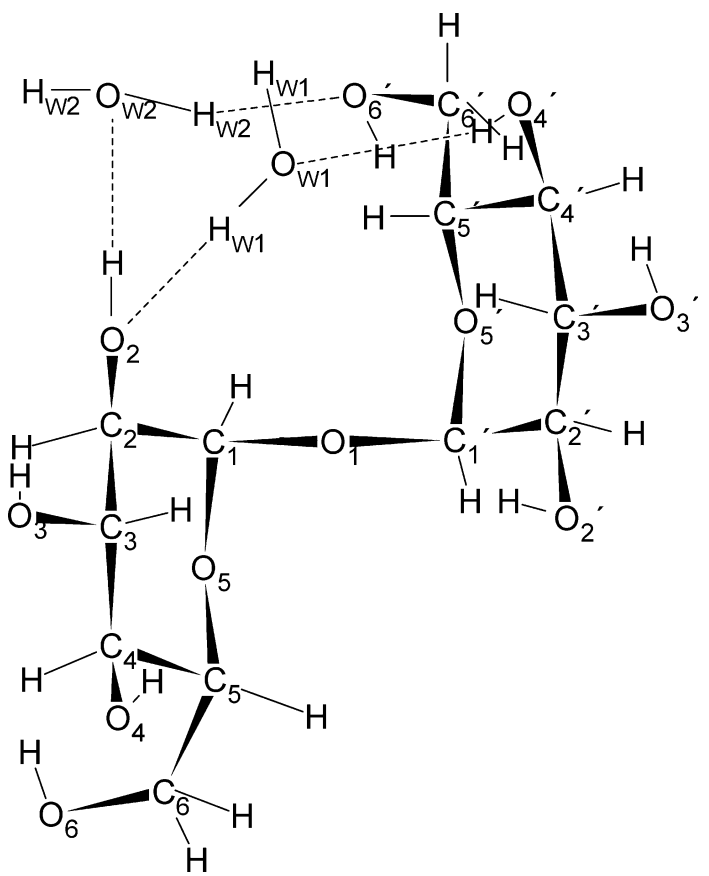

Fig. 1 Trehalose ( $\alpha$-D-glucopyranosyl- $\alpha$-D-glucopyranoside) dihydrate. After [74]

omal protein kinases, including $\mathrm{p} 90^{\mathrm{rsk}}$, in an IR kinaseindependent manner [40, 41, 42, 43, 44].

On the other hand, vanadium compounds also show some toxic effects, which depend on several factors such as the oxidation state, the coordination sphere and the cell type or tissue investigated $[6,45,46]$. Studies with vanadium(IV) complexes of ascorbic acid and monosaccharides have demonstrated that these compounds cause substantial single-strand breaks in DNA and produce lipid peroxidation [47]. However, some of the known monosaccharide complexes of vanadium(IV) also present an interesting protective activity against the degradation of RNA because they inhibit RNase activity [48].

Various organically chelated vanadium compounds are more potent to facilitate insulin-like effects in vitro and in vivo than the simple vanadium salts $[49,50,51]$. Since vanadium absorption is poor in the gastrointestinal tract, the use of organic ligands should increase the lipophilicity of vanadium increasing the gastrointestinal absorption, and thereby decreasing the dose of vanadium required to produce its effects [52]. The synthesis of vanadium complexes with sugars $[53,54,55]$ is of considerable interest in vanadium biochemistry because they are easily and quickly assimilated by plants and animals and especially in relation to the vanadium metabolism and its biological detoxification [56, 57, 58].

The present study deals with the synthesis and the physicochemical characterization of a new vanadium(IV) complex with the disaccharide trehalose ( $\alpha$-D-glucopyranosyl- $\alpha$-D-glucopyranoside) (Fig. 1), and also with the study of its biological effects and putative mechanism of action on osteoblast-like cells in culture. 


\section{Materials and methods}

Materials

$\mathrm{VOCl}_{2}(50 \%$ aqueous solution) was purchased from Carlo Erba; trehalose dihydrate, crystal violet, $p$-nitrophenyl phosphate ( $p$-NPP), glycine, $\mathrm{MgCl}_{2}$ and all the other chemicals used were of analytical grade from Sigma.

Fresh stock solutions of the complex (TreVO) and the free ligand (trehalose) were prepared in distilled water at a $100 \mathrm{mM}$ concentration and diluted according to the concentrations indicated in the legends to the figures.

Tissue culture materials were purchased from Corning (Princeton, NJ, USA), Dulbecco's Modified Eagles Medium (DMEM), DMEM low glucose and trypsin-EDTA from Gibco (Gaithersburg, Md., USA) and fetal bovine serum (FBS) from GibcoBRL (Life Technologies, Germany). An ECL kit was provided by Amersham Life Sciences. The specific antibody rabbit polyclonal IgG anti-ERK (K-23), mouse monoclonal anti-p-ERK (E-4), anti-rabbit IgG-HRP and anti-mouse IgG-HRP were purchased from Santa Cruz Biotechnology. PD98059 was obtained from Calbiochem (USA and Canada), wortmannin and L-ascorbic acid (vitamin C) from Sigma. (+)- $\alpha$-Tocopherol acid succinate (vitamin E) was a gift from Scherer (Buenos Aires, Argentina). Wiener Laboratories (Argentina) provided the glucose oxidase kit.

\section{Synthesis of TreVO: $\mathrm{Na}_{6}\left[\mathrm{VO}(\text { Tre })_{2}\right] \cdot 4 \mathrm{H}_{2} \mathrm{O}$}

$\operatorname{VOCl}_{2}(50 \%$ aqueous solution, $2 \mathrm{mmol})$ was added dropwise to a stirred aqueous solution $(10 \mathrm{~mL})$ of trehalose $(4 \mathrm{mmol})$. The solution $\mathrm{pH}$ was adjusted to 13 by addition of solid $\mathrm{NaOH}$. Upon the addition of absolute ethanol, a microcrystalline powder was formed. The solid was filtered and washed with absolute ethanol. The hygroscopic sodium salt of the complex was stored in an oven at $60{ }^{\circ} \mathrm{C}$ until its physicochemical characterization; yield: $90 \%$.

Physicochemical characterization

Diffuse reflectance spectra were recorded on a Shimadzu UV-300 spectrophotometer. Infrared spectra were recorded on a PerkinElmer 580B spectrophotometer using the $\mathrm{KBr}$ pellet technique. Room temperature magnetic susceptibility was determined with a Cahn-2000 balance, calibrated with $\mathrm{Hg}\left[\mathrm{Co}(\mathrm{SCN})_{4}\right]$ and at a magnetic field strength of $6 \mathrm{kG}$. Elemental analysis for carbon and hydrogen were performed using a Carlo Erba EA 1108 analyzer. Flame photometry and the tungstophosphovanadic method $[59,60]$ were employed to determine sodium and vanadium contents, respectively. Thermogravimetric (TGA) and differential thermal analysis (DTA) were performed on a Shimadzu system (models TG-50 and DTA-50, respectively), working in an oxygen flow of $60 \mathrm{~mL} / \mathrm{min}$ and at a heating rate of $10^{\circ} \mathrm{C} / \mathrm{min}$. Sample quantities ranged between 10 and $20 \mathrm{mg}$. $\mathrm{Al}_{2} \mathrm{O}_{3}$ was used as a DTA standard.

\section{Cell culture}

MC3T3E1 osteoblastic mouse calvaria-derived cells and UMR106 rat osteosarcoma-derived cells were grown in DMEM supplemented with $100 \mathrm{U} / \mathrm{mL}$ penicillin, $100 \mu \mathrm{g} / \mathrm{mL}$ streptomycin and $10 \%(\mathrm{v} / \mathrm{v})$ fetal bovine serum (FBS) at $37{ }^{\circ} \mathrm{C}, 5 \% \mathrm{CO}_{2}$. When $70-80 \%$ confluence was reached, the cells were sub-cultured using $0.1 \%$ trypsin $+1 \mathrm{mM}$ EDTA in $\mathrm{Ca}^{2+} / \mathrm{Mg}^{2+}$-free phosphate buffered saline (PBS) (11 mM KH $\mathrm{PO}_{4}, 26 \mathrm{mM} \mathrm{Na} \mathrm{HPO}_{4}, 115 \mathrm{mM}$ $\mathrm{NaCl}, \mathrm{pH}$ 7.4) $[13,22]$. For experiments the cells were grown in multi-well plates. When the cells reached $70 \%$ confluence, the monolayers were washed twice with DMEM and were incubated under different conditions according to the experiments.
Cell proliferation assay

A mitogenic bioassay was carried out as described by Okajima et al. [61], with some modifications. Briefly, the cells were grown in 48-well plates. When the cells reached $60 \%$ confluence, the monolayers were washed twice with serum-free DMEM and incubated either with different concentrations of TreVO $(2.5-100 \mu \mathrm{M})$ alone, or TreVO plus PD98059 $(10 \mu \mathrm{M})$, wortmannin $(1 \mu \mathrm{M})$ or a mixture of vitamins $\mathrm{E}$ and $\mathrm{C}$ ( $50 \mu \mathrm{M}$ each), according to the figure legends. Then, the monolayers were washed with PBS buffer and fixed with $5 \%$ glutaraldehyde/PBS at room temperature for $10 \mathrm{~min}$. After that, they were stained with $0.5 \%$ crystal violet $/ 25 \%$ methanol for $10 \mathrm{~min}$. Then the dye solution was discarded and the plate was washed with water and dried. The dye taken up by the cells was extracted using $0.5 \mathrm{~mL} /$ well $0.1 \mathrm{M}$ glycine/ $\mathrm{HCl}$ buffer, $\mathrm{pH} 3.0$, in $30 \%$ methanol and transferred to test tubes. Absorbance was read at $540 \mathrm{~nm}$ after a convenient sample dilution. We have previously shown that under these conditions the colorimetric bioassay strongly correlated with the cell proliferation measured by cell counting in a Neubauer chamber [13, 22].

\section{Cell differentiation assay}

Alkaline phosphatase (ALP) specific activity has been used as a marker of osteoblast phenotype [13, 22, 62]. Cells were grown in 24-well plates until $70-80 \%$ confluence, and the monolayers were washed twice with serum-free DMEM. Then the cells were incubated overnight with serum-free DMEM and different doses of TreVO $(2.5-100 \mu \mathrm{M})$ alone, or TreVO plus PD98059 $(10 \mu \mathrm{M})$, wortmannin $(1 \mu \mathrm{M})$ or a mixture of vitamins $\mathrm{E}$ and $\mathrm{C}(50 \mu \mathrm{M}$ each), according to the figure legends. The cell layer was then washed with PBS and solubilized in $0.5 \mathrm{~mL} 0.1 \%$ Triton X-100. Aliquots of the total cell extract $(10-20 \%)$ were used for protein determination by the Bradford technique [63]. Measurement of ALP activity was carried out by spectrophotometric determination of initial rates of hydrolysis of $p$-NPP to $p$-nitrophenol ( $p$-NP) at $37{ }^{\circ} \mathrm{C}$ for $10 \mathrm{~min}$. The reaction mixture consisted of $10 \mu \mathrm{L}$ of cell extract in $800 \mu \mathrm{L}$ of glycine buffer $(55 \mathrm{mM}$ glycine, $0.55 \mathrm{mM}$ $\mathrm{MgCl}_{2}, \mathrm{pH} 10.5$ ). The reaction was initiated by the addition of $100 \mu \mathrm{L}$ of substrate solution to $5 \mathrm{mM} p$-NPP in glycine buffer. The production of $p$-NP was determined by the absorbance at $405 \mathrm{~nm}$. Under these experimental conditions the product formation was linear for $15 \mathrm{~min}$.

\section{Glucose consumption assay}

Cells were subcultured in 48 -well plates. When the cells reached $90 \%$ confluence, the monolayers were washed twice with serumfree DMEM low glucose. Then they were incubated in serum-free DMEM low glucose either with different concentrations of TreVO $(2.5-100 \mu \mathrm{M})$ alone, or TreVO plus PD98059 $(10 \mu \mathrm{M})$, wortmannin $(1 \mu \mathrm{M})$ or a mixture of vitamins $\mathrm{E}$ and $\mathrm{C}(50 \mu \mathrm{M}$ each $)$, according to the figure legends. After $10 \mathrm{~h}$ at $37^{\circ} \mathrm{C}$, the conditioned medium was removed and centrifuged at $5000 \times g$ for $3 \mathrm{~min}$. The cell layer was then washed with PBS and solubilized in $0.5 \mathrm{~mL} 0.1 \%$ Triton X-100. Aliquots of the total cell extract were kept for protein determination using the Bradford technique [63]. The glucose concentration remaining in the conditioned medium was measured by the glucose oxidase enzymatic method, as described previously [61].

\section{Western blotting of cell lysates}

MC3T3E1 and UMR106 osteoblastic-like cells were subcultured into 12-well plates in DMEM supplemented with $100 \mathrm{U} / \mathrm{mL}$ penicillin, $100 \mu \mathrm{g} / \mathrm{mL}$ streptomycin and $10 \%(\mathrm{v} / \mathrm{v}) \mathrm{FBS}$ at $37^{\circ} \mathrm{C}, 5 \%$ $\mathrm{CO}_{2}$. When $100 \%$ confluence was reached, the medium was removed and the cells were washed twice with serum-free DMEM. 
The cells were incubated in serum-free DMEM either with insulin, different concentrations of TreVO alone or TreVO plus PD98059, wortmannin or a mixture of vitamins $\mathrm{E}$ and $\mathrm{C}$, for different periods, according to the figure legends. The cells were washed twice with cold PBS and lysed in Laemmli buffer [64]. Protein content was determined in each lysated cellular fraction. Aliquots with equal amounts of protein were separated on $12.5 \%$ SDS-PAGE under reducing conditions. Then they were transferred to nitro-cellulose membranes, and examined by immunoblotting with specific antibodies against the phosphorylated (1:3000) and non-phosphorylated (1:1000) ERK-1/2 and revealed by an ECL commercial kit.

\section{Stability studies}

To test the stability of TreVO under the different experimental conditions used in this work we analyzed the $\mathrm{pH}$ and UV-visible spectra of different solutions of the complex. TreVO $(50 \mathrm{mM})$ solutions in distilled water, DMEM medium and DMEM plus $0.5 \%$ DMSO, $50 \mu \mathrm{M}$ PD98059 and a mixture of vitamins $\mathrm{C}$ and $\mathrm{E}$ (50 $\mu \mathrm{M}$ each) were prepared. The electronic spectra were recorded at times ranging from 0 to $48 \mathrm{~h}$. The rate of decomposition of TreVO was spectrophotometrically measured at $720 \mathrm{~nm}$ (this wavelength corresponds to the $b_{2} \rightarrow$ e electronic absorption band $[53,54,55])$. The decomposition rate constants were estimated.

We also studied the $\mathrm{pH}$ changes under different experimental conditions.

Statistical methods

At least three independent experiments were performed for each experimental condition. Results are expressed as the mean \pm SEM. Statistical differences were analyzed using Student's $t$-test.

\section{Results}

Elemental analysis

Anal. calcd. for $\mathrm{C}_{24} \mathrm{H}_{44} \mathrm{Na}_{6} \mathrm{O}_{27} \mathrm{~V}$ (953): C, 30.2; H, 4.6; $\mathrm{Na}, 14.5 ; \mathrm{V}, 5.3 \%$. Found: C, 29.9; H, 4.8; Na, 14.6; V, $5.2 \%$. These results account for the molecular formula $\mathrm{Na}_{6}\left[\mathrm{VO}(\text { Tre })_{2}\right] \cdot 4 \mathrm{H}_{2} \mathrm{O}$, later confirmed through the thermal decomposition results (see below).

\section{Magnetic susceptibility}

The sodium salt shows a magnetic moment $\mu_{\mathrm{eff}}=1.9 \mathrm{BM}$ at room temperature. This value indicates that the vanadium center is in a $\mathrm{d}^{1}$ electronic configuration [60]. The experimental $\mu_{\text {eff }}$ is close to the spin-only value, $1.73 \mathrm{BM}$, at room temperature.

\section{Thermal behavior}

The TGA plot under oxygen flow shows two degradation steps at $50{ }^{\circ} \mathrm{C}$ and $121{ }^{\circ} \mathrm{C}$. These steps correspond first to the loss of a water molecule $(1.9 \%$ obs., $1.9 \%$ calcd.) and then to the three remaining ones, respectively (5.6\% obs., $5.7 \%$ calcd.). The degradation of the anhydrous complex occurs in three steps in the ranges 176-471, 471-566 and 566-1000 ${ }^{\circ} \mathrm{C}$. DTA signals were:

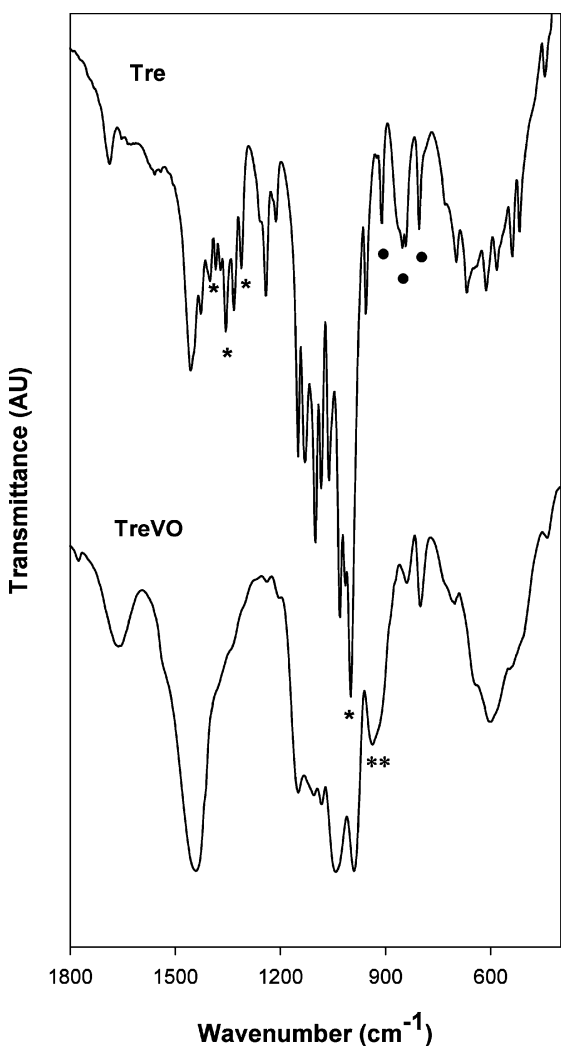

Fig. 2 IR spectra of trehalose (Tre) and $\mathrm{Na}_{6}\left[\mathrm{VO}(\text { Tre })_{2}\right] .4 \mathrm{H}_{2} \mathrm{O}$ (TreVO). Transmittance in arbitrary units. Single asterisks: bands that change upon complexation. Double asterisks: new band, $\mathrm{V}=\mathrm{O}$ stretching. Solid spots: unchanged bands

$233 \mathrm{w}$, exo; 293 vs, exo. The total weight loss corresponds to the formation of $\mathrm{NaVO}_{3}$, as detected by IR spectroscopy. The overall degradation process corresponds to the following equation:

$2 \mathrm{Na}_{6}\left[\mathrm{VO}(\text { Tre })_{2}\right] \cdot 4 \mathrm{H}_{2} \mathrm{O} \stackrel{\mathrm{O}_{2}}{\longrightarrow} 2 \mathrm{NaVO}_{3}+5 \mathrm{Na}_{2} \mathrm{O}$

The observed final weight $(29.1 \%)$ agrees with the calculated value $(29.1 \%)$.

\section{Diffuse reflectance}

The spectrum of the complex shows the three bands typical of sugar complexes with the vanadyl(IV) cation $[53,54,55]$. These bands are centered at 420, 500 and $740 \mathrm{~nm}$

\section{Infrared studies}

The vibrational spectrum of the vanadyl(IV) complex, TreVO, and that of the free ligand, Tre, can be seen in Fig. 2. The bands at $805 \mathrm{~cm}^{-1}$ and $910 \mathrm{~cm}^{-1}$ indicate that the glucose moieties of trehalose are present as the $\alpha$-anomer in the pyranose form. Moreover, the band at $845 \mathrm{~cm}^{-1}$ is indicative of the $\alpha$-configuration of the 
glycosidic bond of the disaccharide $[65,66,67,68,69$, $70,71,72]$. These bands have not changed upon complexation. In the TreVO IR spectrum, the band at $1398 \mathrm{~cm}^{-1}[\delta \mathrm{C}(2) \mathrm{H}]$ disappears upon complexation. The bands at $1355 \mathrm{~cm}^{-1}$ and $1013 \mathrm{~cm}^{-1}(\delta \mathrm{COH})$ are sensitive to deuteration [71], and to the coordination to the metal center. By complexation the $\delta \mathrm{COH}\left[\mathrm{C}(6) \mathrm{H}_{2} \mathrm{OH}\right]$ band at $1309 \mathrm{~cm}^{-1}$ disappears owing to the deprotonation of the $\mathrm{OH}$ groups. Finally, the new band observed at $941 \mathrm{~cm}^{-1}$ corresponds to the $v(\mathrm{~V}=\mathrm{O})$ stretching mode. The position of this band is similar that of other vanadyl(IV) complexes with saccharides previously reported by our group ([53, 54, 55] and references therein).

These observations suggest that the cation is coordinated by the ligand through the deprotonated $\mathrm{OH}$ group at $\mathrm{C}(2)$. It is well known that, in the case of neutral sugars, complexation is favored by basic media and occurs only with molecules possessing adjacent cishydroxyl groups $[53,54,55]$. Considering that there is not another $\mathrm{OH}$ group in a cis position near $\mathrm{C}(2)$, it is difficult to determine with certainty the other chelating group belonging to the second glucose moiety of trehalose. The crystal structure of $\alpha, \alpha$-trehalose dihydrate has been previously described in detail [73, 74, 75]. It has been demonstrated that, apart from the glycosidic bond between $C(1)$ and $C(1 ')$, the two glucopyranosyl moieties of threhalose are also indirectly linked through hydrogen bonds of the two water molecules of the dihydrate. One bound water molecule $\left(\mathrm{w}_{1}\right)$ is linked by hydrogen bonding to both $\mathrm{O}(2)$ and to $\mathrm{O}\left(4^{\prime}\right)$. The other bound water molecule $\left(\mathrm{w}_{2}\right)$ is linked to both $\mathrm{O}(2)$ and to $\mathrm{O}\left(6^{\prime}\right)$ (Fig. 1). It is reasonable to think that in TreVO the vanadyl(IV) cation interacts with $\mathrm{O}(2)$ and it may form the chelate through $\mathrm{O}\left(4^{\prime}\right)$ or $\mathrm{O}\left(6^{\prime}\right)$. These groups constitute cis pairs of donors adequate for this interaction.

Effect of TreVO on the osteoblast-like cell proliferation

Figure 3 shows the effect of different TreVO concentrations on the proliferation of MC3T3E1 and UMR106 osteoblast-like cells, determined by crystal violet bioassay. After a 24 -h culture, $5 \mu \mathrm{M}$ TreVO significantly increased UMR 106 cell proliferation $(105 \%$ over basal, $P<0.05)$. A stronger mitogenic effect was observed in the non-transformed MC3T3E1 line, in which 5-25 $\mu \mathrm{M}$ TreVO significantly stimulated cell growth, ranging from 111 to $114 \%$ over basal $(P<0.01)$. On the other hand, higher doses of the vanadium complex showed a cytotoxic effect on both osteoblastic lines, although this effect was stronger in the UMR106 than in the MC3T3E1 cells. Thus, at $75-100 \mu \mathrm{M}$ concentrations, a slight but statistically significant inhibition of MC3T3E1 growth $(10 \%, P<0.02)$ was observed, while $50-100 \mu \mathrm{M}$ TreVO decreased UMR106 cell proliferation in the range $20-45 \%$ of control $(P<0.002)$. Moreover, the free ligand (trehalose) did not exert any effect on either cell line in the whole range of tested concentrations. In

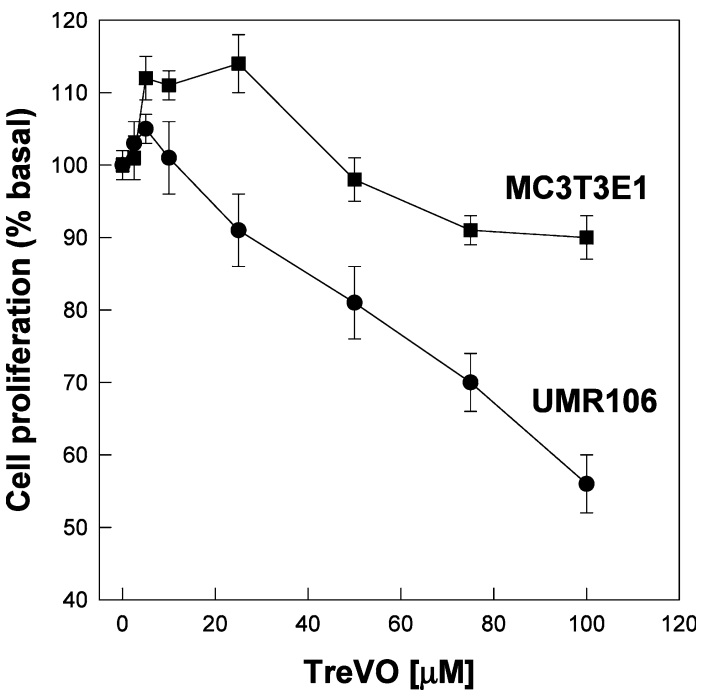

Fig. 3 Effect of TreVO on MC3T3E1 and UMR106 osteoblast-like cell proliferation. Cells were incubated in serum-free DMEM alone (basal) or with different concentrations of TreVO at $37{ }^{\circ} \mathrm{C}$ for $24 \mathrm{~h}$. Results are expressed as \% basal and represent the mean \pm SEM $(n=12)$

previous work we have reported that the vanadyl(IV) cation stimulated UMR106 proliferation in the same range $[13,23]$. In MC3T3E1 cells, the vanadyl(IV) cation was an inhibitory agent in the range $10-100 \mu \mathrm{M}$ [25].

In an attempt to define the mechanism by which TreVO stimulates MC3T3E1 cell proliferation, we next examined the effect of different inhibitors of the ERK pathway such as wortmannin, PD98059 and also the effect of a mixture of vitamins $\mathrm{E}$ and $\mathrm{C}$ (free radical scavengers). As can bee seen in Fig. 3, at $25 \mu \mathrm{M}$ concentration, TreVO significantly increased cell proliferation $(118 \%$ over basal, $P<0.01)$. This stimulatory effect was totally abolished by either PD98059 or wortmannin, but not by a mixture of vitamins $\mathrm{C}$ and $\mathrm{E}$. These observations suggest the involvement of a PI3K-ERK pathway in the mitogenic action of TreVO. In control experiments, the effect of ERK inhibitors or the mixture of vitamins (without vanadium complex) was also evaluated for possible cytotoxicity. It should be noted that, under these conditions, none of these agents affected cell growth (Fig. 4).

On the other hand, we also investigated the mechanism by which higher doses of TreVO-induced osteoblastic cytotoxicity. However, wortmannin, PD98059 or a mixture of vitamins $\mathrm{E}$ and $\mathrm{C}$ did not prevent this effect for the vanadium complex.

\section{Effect of TreVO on osteoblastic differentiation}

The effect of the trehalose vanadium(IV) complex on osteoblast-like cell differentiation was assessed by ALP specific activity, as described in Materials and methods. As can be seen from Fig. 5, TreVO (5-100 $\mu \mathrm{M})$ significantly inhibited UMR106 cell differentiation in the 


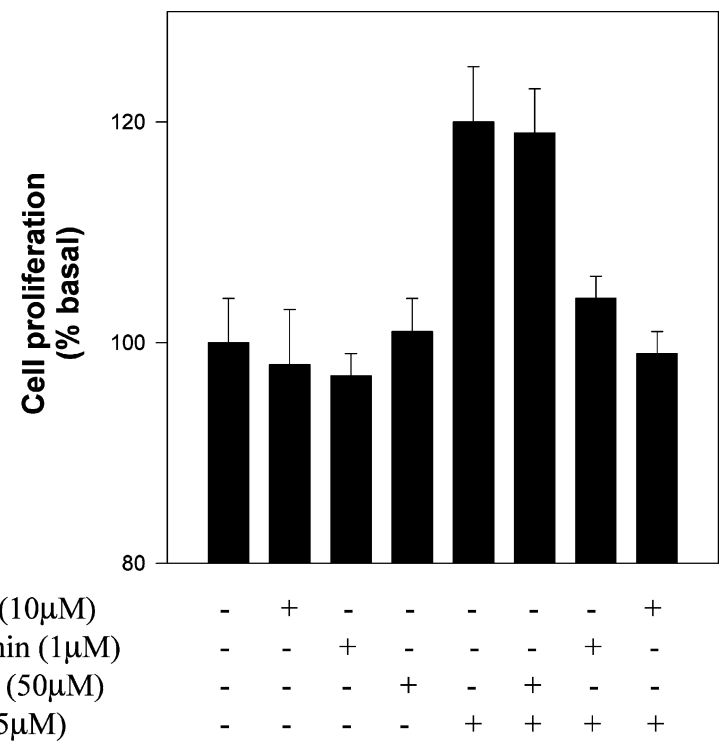

Fig. 4 Effect of inhibitors on TreVO-induced MC3T3E1 cell proliferation. Osteoblast-like cells were incubated at $37{ }^{\circ} \mathrm{C}$ for $24 \mathrm{~h}$ in DMEM alone (basal), DMEM plus PD98059 $(10 \mu \mathrm{M})$ or wortmannin $(1 \mu \mathrm{M})$, or a mixture of vitamins $\mathrm{E}$ and $\mathrm{C}(50 \mu \mathrm{M}$ each) (controls), and in DMEM plus TreVO or TreVO plus inhibitors. Cell proliferation was determined by the crystal violet bioassay. Results are expressed as $\%$ basal and represent the mean $\pm \operatorname{SEM}(n=9)$

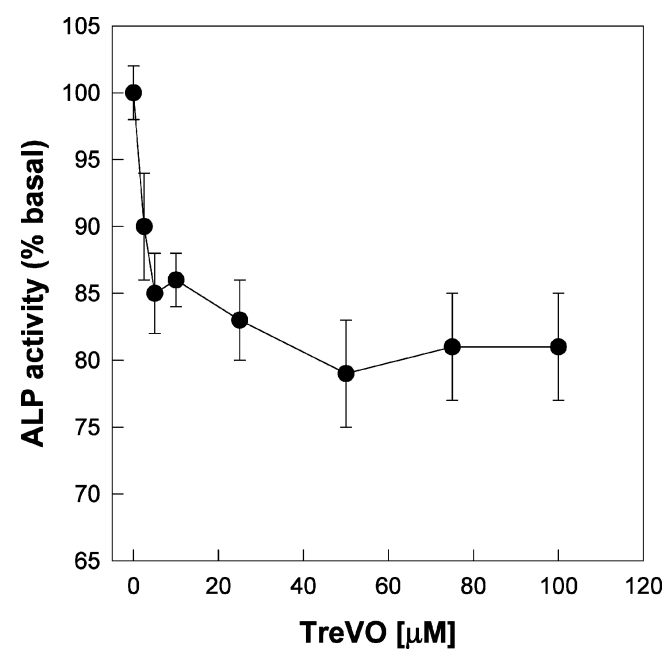

Fig. 5 Effect of TreVO on osteoblast-like cell differentiation. UMR106 cells were incubated either in serum-free DMEM alone (basal) or with different concentrations of TreVO at $37^{\circ} \mathrm{C}$ for $24 \mathrm{~h}$. Basal activity was $1 \mu \mathrm{mol} p \mathrm{NP} / \mathrm{min} \times \mathrm{mg}$ protein. Results are expressed as $\%$ basal and represent the mean $\pm \operatorname{SEM}(n=9)$

range of $15-25 \%$ of basal $(P<0.001)$. These results are in agreement with our previous studies in which the vanadyl cation was shown to be a weak inhibitor of the osteoblastic differentiation $[13,23]$ in comparison with vanadium $(V)$ compounds. Since the MC3T3E1 cells do not express measurable ALP levels after short culture periods (3 days) [76], the effect of TreVO was not assessed in this cell line.

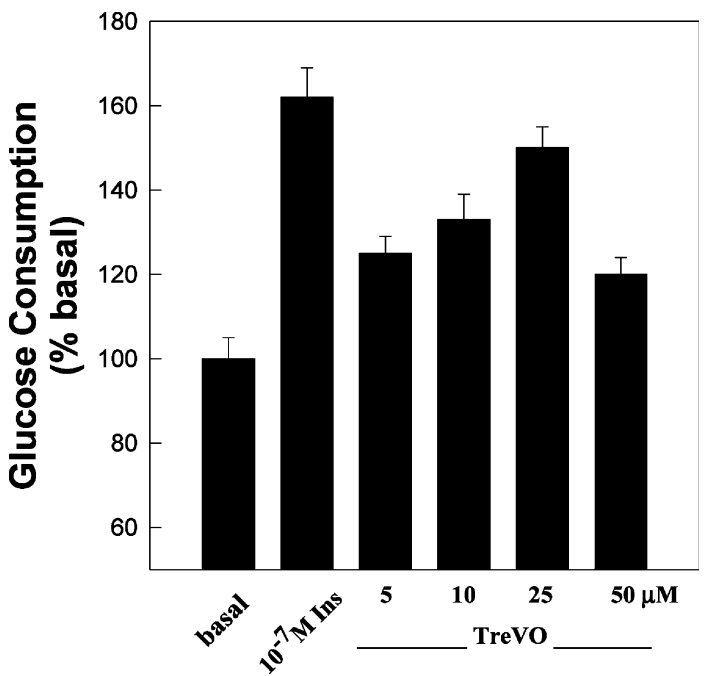

Fig. 6 Effect of TreVO on glucose consumption. UMR106 cells were incubated either with DMEM alone (basal), $10^{-7} \mathrm{M}$ insulin or different concentrations of $\mathrm{TreVO}$ at $37^{\circ} \mathrm{C}$ for $10 \mathrm{~h}$. Basal glucose consumption was $1.2 \pm 0.06 \mathrm{mg}$ glucose $/ \mathrm{mg}$ protein. Results are expressed as $\%$ basal and represent the mean $\pm \operatorname{SEM}(n=9)$

TreVO and insulin stimulate glucose consumption in osteoblast-like cells by a mechanism independent of PI3-K

We next determined whether or not TreVO was able to stimulate glucose consumption in osteoblast-like cells in culture. The vanadium complex increased glucose consumption at a similar extent in both MC3T3E1 and UMR106 osteoblastic lines. Figure 6 shows the results of different concentrations of TreVO and $10^{-7} \mathrm{M}$ insulin on the glucose consumption in UMR106 cells. TreVO increased the consumption of glucose in a dose-dependent manner, with a maximum effect at a concentration of $25 \mu \mathrm{M}$.

In an attempt to define the mechanism of action of TreVO-stimulated glucose consumption, we studied the effect of wortmannin over this parameter. UMR106 osteoblast-like cells were pre-incubated with different concentrations of wortmannin $(0.1,1$ and $10 \mu \mathrm{M})$ during several periods of time $(0.5,1$ and $3 \mathrm{~h})$ followed by a 10 -h culture of either $25 \mu \mathrm{M}$ TreVO or $10^{-7} \mathrm{M}$ insulin. Stimulation of glucose consumption by insulin or TreVO was not affected by wortmannin under any of the above conditions. These results are in contrast to previous observations in other cell types [77, 78], and suggest that insulin and TreVO could stimulate glucose consumption in UMR106 and MC3T3E1 osteoblast-like cells without activating PI3-K.

TreVO-induced activation of ERK-1/2

in osteoblast-like cells

To investigate the signal transduction pathways involved in the mechanism of action of the TreVO complex, we 


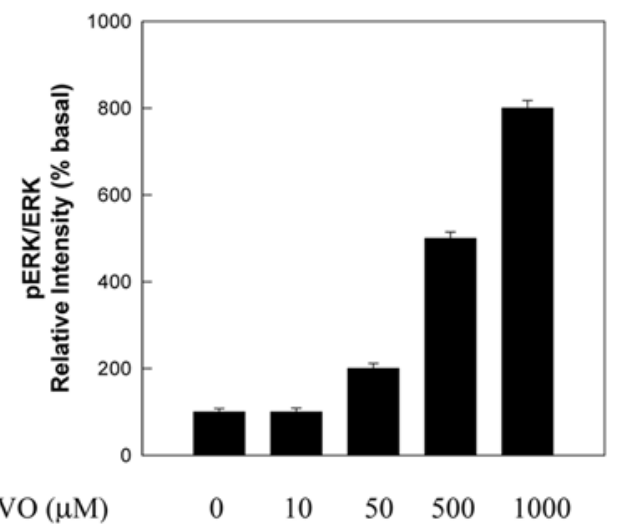

b
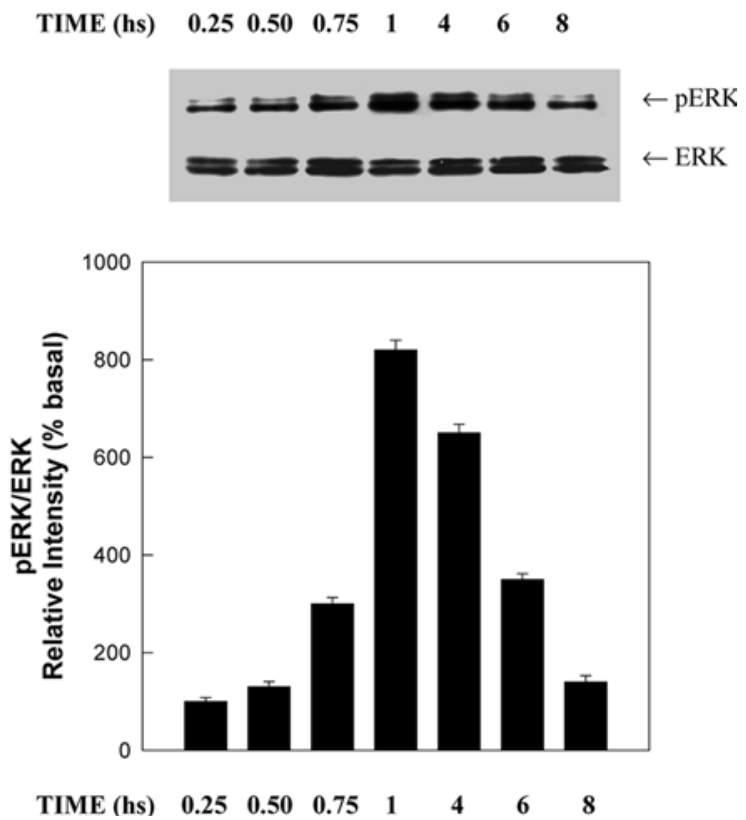

Fig. 7 Dose-response (A) and time course (B) of TreVO-induced ERK phosphorylation. Confluent UMR106 cells were treated with different concentrations of TreVO for $1 \mathrm{~h}$ (A) or with $500 \mu \mathrm{M}$ TreVO for different periods of time (B). Cells were lysed and proteins were separated by SDS-PAGE and transferred to nitrocellulose membrane. For immunoblots, either anti-phosphoERK or anti-ERK antibodies were used for previous stripping. Relative intensities of stimulation were corrected for total ERK, as determined by densitometry and are expressed as \% basal. Similar results were obtained in three independent experiments performed by triplicates

examined its effect on the activation of ERK. Proteins in the cell extracts were separated by electrophoresis and examined by immunoblotting with specific antibodies against the phosphorylated and non-phosphorylated forms of ERK-1/2. A representative immunoblot is shown for ERK and p-ERK in Fig. 7. TreVO stimulated the ERK phosphorylation in a dose-dependent manner (Fig. 7A), from 50 to $1000 \mu \mathrm{M}$. This effect was also dependent on the time of incubation (Fig. 7B). As can be seen, the maximum effect of $500 \mu \mathrm{M}$ was reached at a 1-h incubation and began to decline thereafter.

In an attempt to define the mechanism by which TreVO induced ERK phosphorylation, we examined the potential role of both oxidative and MAPK pathways. Osteoblasts were pre-incubated either with a mixture of vitamins $\mathrm{E}$ and $\mathrm{C}$ (free radical scavengers), wortmannin (a PI3-K inhibitor), PD98059 (a MEK inhibitor) or a combination of the previous conditions. Control experiments were also carried out with a mixture of vitamins $\mathrm{E}$ and C, wortmannin, PD98059, a vehicle (DMSO) and their combination. Finally, 25 or $1000 \mu \mathrm{M}$ TreVO were added for an additional $1 \mathrm{~h}$ and the activation of ERK was assessed as before.

Figure 8 shows the effect of the inhibitors on the ERK phosphorylation induced by low doses $(25 \mu \mathrm{M})$ of TreVO in the MC3T3E1 cell line. The stimulatory effect $(175 \%$ over basal, $P<0.001)$ of the vanadium complex was totally blunted by either PD98059 or wortmannin. However, the mixture of vitamins $\mathrm{E}$ and $\mathrm{C}$ did not affect the TreVO-induced ERK activation. These results suggest that the effect of low doses of the TreVO complex could occur through the PI3K-MEK-ERK pathway and seems to be independent of the formation of free radicals in these cells.

On the other hand, the ERK phosphorylation induced by high concentrations of TreVO $(1000 \mu \mathrm{M})$ was partially inhibited by wortmannin, PD98059 or a mixture of vitamins (Fig. 9). An additive effect could be observed when the cells were incubated with the mixture of inhibitors, thus totally abrogating the effect of TreVO on ERK activation. For comparison, the effect of insulin in the osteoblastic cells was also investigated. Insulin $\left(10^{-7} \mathrm{M}\right)$ stimulated ERK phosphorylation fourfold, an effect that was inhibited by either wortmannin or PD98059, but not by a mixture of vitamins E and C. Altogether, these results suggest that the activation of ERK at higher concentrations of TreVO could occur through at least two mechanisms, one dependent on and the other independent of the oxidative stress.

Stability of TreVO under different experimental conditions

Under our experimental conditions, the decomposition reaction of TreVO is first order in the concentration of the complex. This dependence is demonstrated by the linearity of the plots of $\ln A$ versus time, where $A$ is the absorbance at $720 \mathrm{~nm}$, measured at time $t$. The decomposition rate of the complex was determined in distilled water at $25{ }^{\circ} \mathrm{C}$, since the stock solution was prepared in this solvent at room temperature. Nevertheless, once prepared, the stock solution was immediately added to 


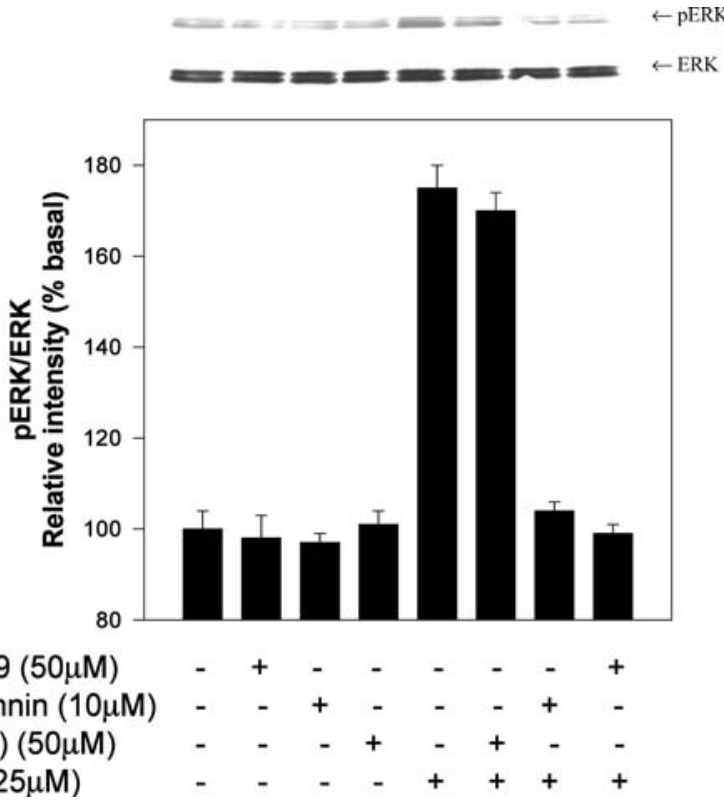

Fig. 8 Effect of inhibitors on ERK activation induced by low doses of TreVO. MC3T3E1 osteoblast-like cells were pre-incubated either with PD98059 $(50 \mu \mathrm{M})$ for $1 \mathrm{~h}$, wortmannin $(10 \mu \mathrm{M})$ for $1 \mathrm{~h}$ or a mixture of vitamins $\mathrm{E}$ and $\mathrm{C}(50 \mu \mathrm{M}$ each) for $6 \mathrm{~h}$, in serum-free DMEM (basal) or plus $25 \mu \mathrm{M}$ TreVO for 1 additional hour. Immunoblots were performed as described in Materials and methods. The relative intensity of stimulation corrected for total ERK was determined by densitometry. Results are expressed as \% basal and are representative of three independent experiments

the culture medium at $37^{\circ} \mathrm{C}$. The rate constant for the decomposition of a $50 \mathrm{mM}$ TreVO solution in distilled water at $25^{\circ} \mathrm{C}$ was $k=1.1 \times 10^{-4} \mathrm{~min}^{-1}$. On the other hand, in DMEM medium at $37^{\circ} \mathrm{C}$ the $k$ value was $2.3 \times 10^{-4} \mathrm{~min}^{-1}$ and in DMEM plus different inhibitors it was $2.8 \times 10^{-4} \mathrm{~min}^{-1}$. Altogether, these results show that although TreVO is stable under our working conditions, its semi-decomposition time is greater in the presence of the oxygen scavengers (vitamins $\mathrm{C}$ and $\mathrm{E}$ ).

On the other hand, the stock solution of $100 \mathrm{mM}$ TreVO in distilled water has a $\mathrm{pH}$ of 11.0. At the maximum concentration used in this work $(1 \mathrm{mM}$ of the complex in DMEM for Western blot experiments), TreVO caused a transitory change of $\mathrm{pH}$ from 7.4 to 8.5 for less than $3 \mathrm{~min}$. Besides, the complex at $100 \mu \mathrm{M}$, which is the highest concentration used in the proliferation, differentiation and glucose consumption assays, did not cause any change in the $\mathrm{pH}$ value of the culture medium.

\section{Discussion}

Many studies carried out in different laboratories have previously demonstrated the insulin-mimetic properties of inorganic vanadium salts on different cell types $[5,6$, 7, 8, 9, 10, 11, 12]. Vanadium compounds exert mitogenic actions, behaving as growth factor mimetic compounds and as metabolic agents. In particular, we

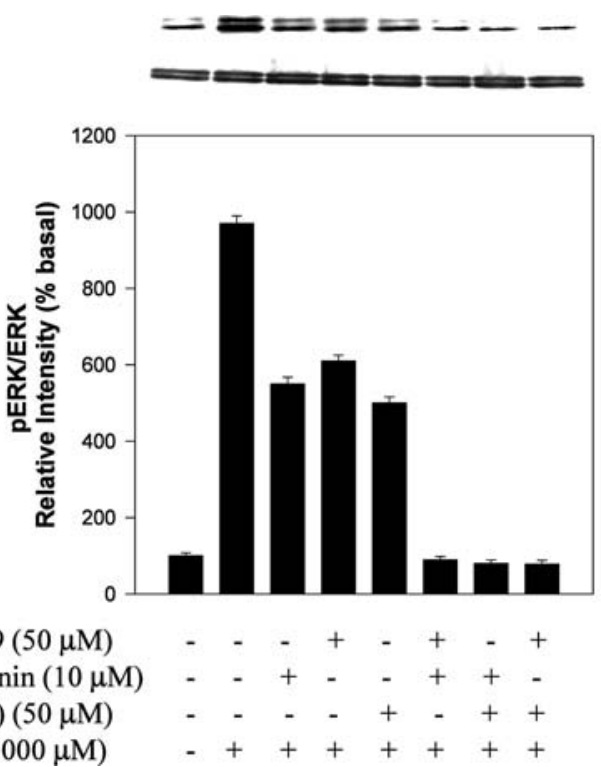

Fig. 9 Effect of inhibitors on ERK activation induced by high doses of TreVO $(1 \mathrm{mM})$. MC3T3E1 osteoblast-like cells were preincubated either with PD98059 $(50 \mu \mathrm{M})$ for $1 \mathrm{~h}$, wortmannin $(10 \mu \mathrm{M})$ for $1 \mathrm{~h}$, a mixture of vitamins $\mathrm{E}$ and $\mathrm{C}$ (50 $\mu \mathrm{M}$ each) for $6 \mathrm{~h}$, a combination of the previous conditions in serum-free DMEM (basal) or plus $1000 \mu \mathrm{M}$ TreVO for 1 additional hour. Immunoblots were performed as described in Materials and methods. Relative intensity of stimulation corrected for total ERK was determined by densitometry. Results are expressed as \% basal and are representative of three independent experiments

have shown their effects on cell proliferation and differentiation as well as on the stimulation of glucose consumption in osteoblast-like cells in culture [13, 21, $22,23,24,25,26,27]$.

As part of a research project devoted to develop new vanadium derivatives with simple sugars and related compounds, we have synthesized and characterized several complexes of the vanadyl(IV) cation with this type of ligand $[53,54,55]$. In this paper, we have synthesized and characterized a new complex of vanadyl(IV) with the disaccharide trehalose, which displays interesting biological activities.

As we have stated above (see Results), the vanadyl cation is linked to trehalose $\mathrm{O}(2)$. Comparing the conformation adopted by this ligand in the reported structure of its dihydrate complex, we assume the participation of either the $\mathrm{O}\left(4^{\prime}\right)$ or $\mathrm{O}\left(6^{\prime}\right)$ in chelate formation $[73,74,75]$.

To determinate the insulin-mimetic activity of TreVO and to investigate its mechanism of action, we have used two osteoblast-like cell lines in culture. One of them is a line derived from mouse calvaria (MC3T3E1) and the other from a rat osteosarcoma (UMR106). We have previously determined the effects upon cellular growth of different vanadium(IV) derivatives [13, 23, 24]. At low doses $(5-25 \mu \mathrm{M})$, the free vanadyl(IV) cation and vanadium compounds stimulate the UMR106 cell proliferation but not the proliferation of the non-transformed MC3T3E1 osteoblasts. In these cells, at low doses, 
TreVO was an effective stimulatory agent on the MC3T3E1 proliferation with a weaker effect on the tumorigenic line UMR106. In addition, at higher concentrations $(75-100 \mu \mathrm{M})$, TreVO was a more potent inhibitor of UMR106 growth than of MC3T3E1 cell proliferation. A selective action of TreVO on cell proliferation, which depends on the concentration and the cellular type, can be seen. These results show that the coordination of vanadyl(IV) with trehalose produced a new complex of vanadium with interesting mitogenic activity.

The signalling mechanism by which vanadium compounds stimulate cell proliferation is at present poorly understood. It has been suggested that one of the possible mechanisms involved in vanadium bioactivity is the regulation of the phosphotyrosine protein level [79]. The insulin-mimetic effects of vanadium may be attributed to its analogy with phosphate and to the stimulation of protein tyrosine phosphorylation through the inhibition of protein tyrosine phosphatases (PTPases) [29, 30] or to the direct stimulation of the kinases [31]. Alternatively, different authors have suggested that the molecular mechanism by which vanadium exerts its biological effects may be due to the formation of reactive oxygen species [80, 81, 82]. Other investigators and our group have brought data towards this direction, demonstrating the induction of thiobarbituric acid reactive substances (TBARS) and reactive oxygen species (ROS) formation upon incubation with different vanadium compounds $[46,83]$. It has been previously shown [39] that the activation of ERK by vanadyl sulfate is dependent on PI3$\mathrm{K}$ activation. On the other hand, various growth factors like platelet-derived growth factor (PDGF) and insulinlike growth factor-I (IGF-I), which act through the receptor tyrosine kinases (RTKs), are able to activate ERK's [35, 36, 37, 38]. The ERK pathway is usually associated with cell proliferation and protection from apoptosis [28, 84].

In our model of osteoblastic cells in culture we have demonstrated the ability of low doses of TreVO to stimulate ERK phosphorylation in MC3T3E1 cell line. This effect was totally abrogated by an inhibitor of MEK (PD98059) and wortmannin, but not by a mixture of free radical scavengers (vitamins $\mathrm{E}$ and $\mathrm{C}$ ) (Fig. 8). These results suggest that low doses of the complex, which are mitogenic for MC3T3E1 cells, could act though the PI3K-MEK-ERK pathway and by a mechanism independent of free radicals. On the other hand, at higher doses, TreVO inhibited cell proliferation in both cell lines. This effect was not blocked by either wortmannin or PD98059, nor by the mixture of vitamins $\mathrm{C}$ and E. However, $1000 \mu \mathrm{M}$ of TreVO strongly increased ERK phosphorylation, an effect that was partially blocked by wortmannin, PD98059 or a mixture of vitamins $\mathrm{E}$ and $\mathrm{C}$. In addition, the combination of these inhibitors showed an additive effect over the inhibition of ERK activation. Altogether these results indicate that, although high doses of TreVO stimulate ERK phosphorylation through the
PI3K-MEK-dependent pathway and also through an oxidative mechanism, the inhibition of cell proliferation does not seem to be associated with the activation of these pathways.

In relation to cell differentiation, the new complex behaves like an inhibitory agent, as has been demonstrated by the inhibition of the specific ALP activity. It is important to stress that TreVO inhibited cell differentiation at low doses $(5-25 \mu \mathrm{M})$. To investigate the mechanism by which the complex produced this effect, we included different inhibitors such as wortmannin, PD98059 and a mixture of vitamins $\mathrm{E}$ and $\mathrm{C}$ in the differentiation assays. These agents were unable to reverse the inhibition produced by TreVO on cell differentiation. Thus, the osteoblastic differentiation does not seem to be mediated by the PI3-K/ERK pathway or the formation of ROS.

Among the cellular events evoked by insulin, the glucose consumption is assumed to occur by the activation of PI3-K, as has been demonstrated in rat adipocytes [77] and rat skeletal muscle [78]. These observations indicate that PI3-K is essential for insulinstimulated glucose consumption in several cell types. However, other authors have suggested that vanadate and pervanadate stimulate glucose consumption in muscle cells by a mechanism independent of PI3-K [85]. Our present results are in agreement with the latter observations. Insulin and TreVO stimulated the glucose consumption in osteoblast-like cells, but the PI3-K inhibitor wortmannin did not abrogate the effect of these agents.

In conclusion, the results of this work are relevant to demonstrate the correlation between several biological effects and the signal transduction pathways involved in the action of a new vanadium(IV) complex with trehalose. This compound could be a potential good candidate for therapeutic applications in the treatment of diseases such as Diabetes mellitus.

Acknowledgements This work was supported by UNLP, CONICET (PIP 1044/89) and ANPCyT (PICT 06-06148). D.A.B. is a fellow of CICPBA, P.A.M.W. and A.M.C. are members of the Carrera del Investigador, CICPBA, Argentina and S.B.E. is a member of the Carrera del Investigador, CONICET, Argentina.

\section{References}

1. Nielsen FH (1995) In: Segel H, Sigel A (eds) Metal ions in biological systems, vol 31. Dekker, New York, pp 543-573

2. Slebodnick C, Hamstra BJ, Pecoraro VL (1997) Struct Bonding 89:51-107

3. Heyliger CE, Tahiliani AG, McNeil JH (1985) Science 227:1474-1477

4. Meyerovitch J, Rothenberg P, Schechter Y, Weir A, Kahn CR (1991) J Clin Invest 87:1286-1294

5. Shechter Y (1990) Diabetes 39:1-5

6. Etcheverry SB, Cortizo AM (1998) In: Nriagu JO (ed) Vanadium in the environment, part 1. Wiley, New York, pp 359-392

7. Hori C, Oka T (1990) Biochim Biophys Acta 610:235-240

8. Smith JB (1983) Proc Natl Acad Sci USA 80:6162-6166

9. Canalis E (1985) Endocrinology 116:855-862 
10. Lau KHW, Tanimoto H, Baylink DJ (1988) Endocrinology 123:2858-2867

11. Kato Y, Iwamoto M, Koike T, Susuky FJ (1987) Cell Biol 104:311-319

12. Davidai G, Lee A, Schvartz Y, Hazum E (1992) Am J Physiol 263:E205-E209

13. Cortizo AM, Etcheverry SB (1995) Mol Cell Biochem 145:97102

14. Shechter Y, Karlish SDJ (1980) Nature 284:556-558

15. Duckworth WC, Solomon SS, Liepnicks J, Hamel FG, Hand S, Peavy DE (1988) Endocrinology 122:2285-2289

16. Tamura S, Brown TA, Whipple JH, Fujita-Yamaguchi Y, Dubler RE, Cheng K, Larner J (1984) J Biol Chem 259:66506658

17. Clark AS, Fagan JM, Mitch WE (1985) Biochem J 232:273-276

18. Thompson KH, McNeill JH, Orvig C (1999) Chem Rev 99:2561-2571

19. Djordjevic C (1995) In: Segel H, Sigel A (eds) Metal ions in biological systems, vol 31. Dekker, New York, pp 595-616

20. Nielsen FH, Uthus EC (1990) In: Chasteen ND (ed) Vanadium in biological systems. Kluwer, Dordrecht, Netherlands, pp $51-62$

21. Cortizo AM, Sálice VC, Vescina CM, Etcheverry SB (1997) BioMetals 10:127-133

22. Etcheverry SB, Crans DC, Keramidas AD, Cortizo AM (1997) Arch Biochem Biophys 338:7-14

23. Barrio DA, Braziunas MD, Etcheverry SB, Cortizo AM (1997) J Trace Elem Med Biol 11:110-115

24. Sálice VC, Cortizo AM, Gómez Dumm CL, Etcheverry SB (1999) Mol Cell Biochem 198:119-128

25. Etcheverry SB, Williams PAM, Barrio DA, Sálice VC, Ferrer EG, Cortizo AM (2000) J Inorg Biochem 80:169-171

26. Etcheverry SB, Williams PAM, Sálice VC, Barrio DA, Ferrer EG, Cortizo AM (2002) BioMetals 15:37-49

27. Etcheverry SB, Barrio DA, Cortizo AM, Williams PAM (2002) J Inorg Biochem 88:94-100

28. Cheathan B, Khan R (1995) Endocrine Rev 116:117-142

29. Swarup G, Cohen S, Garbers DI (1982) Biochem Biophys Res Commun 107:1104-1109

30. Tracey AS, Gresser MJ (1986) Proc Natl Acad Sci USA 83:609-613

31. Shisheva A, Shechter Y (1992) FEBS Lett 23:93-96

32. Cano E, Mahadevan LC (1995) Trends Biochem Sci 20:117122

33. Marshall CJ (1995) Cell 80:179-185

34. Robinson MJ, Cobb MH (1997) Curr Opin Cell Biol 9:180-186

35. Chaudhary LR, Avioli LV (1997) Biochem Biophys Res Commun 238:134-139

36. Zhen X, Bonjour JP, Caverzacio J (1997) J Bone Miner Res $12: 36-44$

37. Kawane T, Horiuchi N (1999) Endocrinology 140:871-879

38. Xia Z, Dickens M, Raingeaud J, Davis RJ, Greenberg ME (1995) Science 270:1326-1331

39. Pandey SK, Théberge JF, Bernier M, Srivastava AK (1999) Biochemistry 38:14667-14675

40. D'Onofrio F, Le MQ, Chiasson JL, Srivastava AK (1994) FEBS Lett 340:269-275

41. Blondel A, Simon J, Chevalier B, Portha B (1990) Am J Physiol 258:E459-E467

42. Shechter Y, Li J, Meyerovitch J, Gefel D, Bruck R, Elberg G, Miller DS, Shisheva A (1995) Mol Cell Biochem 153:39-47

43. Fantus IG, Kadota S, Deragon G, Foster B, Posner BI (1989) Biochemistry 28:558-563

44. Pandey SK, Chiasson JL, Srivastava AK (1995) Mol Cell Biochem 153:69-78

45. Domingo JL (1996) Reprod Toxicol 10:175-182

46. Cortizo AM, Bruzzone L, Molinuevo S, Etcheverry SB (2000) Toxicology 147:89-99

47. Sreedhara A, Susa N, Patwardhan A, Rao CP (1996) Biochem Biophys Res Commun 35:79-93

48. Sreedhara A, Rao CP, Rao BJ (1996) Carbohydr Res 289:39-53
49. McNeill JH, Yuen VG, Hoveyda HR, Orvig C (1992) J Med Chem 35:1489-1491

50. Shechter Y, Shisheva A, Lazar R, Libman J, Shanzer A (1992) Biochemistry 31:2063-2068

51. Goldwaser I, Qian S, Gershonov E, Fridkin M, Shechter Y (2000) Mol Pharmacol 58:738-746

52. Underwood EJ (1977) Trace elements in human and animal nutrition. Academic Press, New York, pp 388-397

53. Etcheverry SB, Williams PAM, Baran EJ (1997) Carbohydr Res 302:131-138

54. Williams PAM, Etcheverry SB, Baran EJ (2000) Carbohydr Res 329:41-47

55. Etcheverry SB, Barrio DA, Williams PAM, Baran EJ (2001) Biol Trace Element Res 84:227-237

56. Baran EJ (1998) In: Nriagu JO (ed) Vanadium in the environment, part 2. Wiley, New York, pp 317-345

57. Baran EJ (2000) J Inorg Biochem 80:1-10

58. Baran EJ (2001) J Carbohydr Chem 20:769-788

59. Onishi M (1988) Photometric determination of traces of metals, part II. Wiley, New York

60. Syamal A (1975) Coord Chem Rev 16:309-339

61. Okajima $T$, Nakamura $K$, Zhang $H$, Ling $N$, Tanabe $T$, Yasuda T, Rosenfeld RG (1992) Endocrinology 130:2201-2212

62. Stein GS, Lian JB (1993) Endocrine Rev 14:424-442

63. Bradford M (1976) Anal Biochem 72:248-254

64. Laemmli EK (1970) Nature 227:680-685

65. Vasko PD, Blackwell J, Koenig JL (1971) Carbohydr Res 19:297-310

66. Cael JJ, Koenig JL, Blackwell J (1974) Carbohydr Res 32:79-91

67. She CY, Dinh ND, Tu AT (1974) Biochim Biophys Acta 372:345-357

68. Tul'chinsky VM, Zurabyan SE, Asankozhoev KA, Kogan GA, Khorlin AY (1976) Carbohydr Res 51:1-8

69. Mathlouthi M, Luu DV (1980) Carbohydr Res 81:203-212

70. Mathlouthi M, Luu C, Meffroy-Byget AM, Luu DV (1980) Carbohydr Res 81:213-223

71. Mathlouthi M, Koenig JL (1993) Adv Carbohydr Chem Biochem 44:7-89

72. Wen ZQ, Barron LD, Hecht LI (1993) J Am Chem Soc 115:285-292

73. Brown GM, Rohrer DC, Berking B, Beevers CA, Gould RO, Simpson R (1972) Acta Crystallogr B 28:3145-3158

74. Taga T, Senma M, Osaki K (1972) Acta Crystallogr B 28:32583262

75. Akao K, Okubo Y, Ikeda T, Inoue Y, Sakurai M (1998) Chem Lett 759-760

76. Quarles DL, Yohay DA, Lever LW, Caton R, Wenstrup R (1992) J Bone Miner Res 7:683-692

77. Okada T, Kawano Y, Sakakibara T, Hazeki O, Ui M (1994) J Biol Chem 269:3568-3573

78. Yeh J, Gulve EA, Rameh L, Birnbaum MJ (1995) J Biol Chem 270:2107-2111

79. Stankiewicz PJ, Tracey AS, Crans DC (1995) In: Sigel H, Sigel A (eds). Metal ions in biological systems, vol 31. Dekker, New York, pp 287-324

80. Wang YZ, Bonner JC (2000) Am J Respir Cell Mol Biol $22 \cdot 590-596$

81. Zhang Z, Huang C, Li J, Leonard SS, Lanciotti R, Butterworth L, Shi X (2001) Arch Biochem Biophys 392:311-320

82. Krejsa CM, Nadler SG, Esseltyn JM, Kavanagh TJ, Ledbetter JA, Schieven GL (1997) J Biol Chem 272:11541-11549

83. Younes M, Strubelt O (1991) Toxicology 66:63-74

84. Kitagawa D, Tenemura S, Ohata S, Shimizu N, SeoJ, Nishitai G, Watanabe T, NakagawaK, Kishimoto H, Wada T, Tezuka T, Yamamoto T, Nishina H, Katada T (2002) J Biol Chem 277:366-371

85. Tsiani E, Bogdanovic E, Sorisky A, Nagy L, Fantus IJ (1998) Diabetes 47:1676-1686 